\title{
Developing Penicillium digitatum Management Strategies on Post-Harvest Citrus Fruits with Metabolic Components and Colonization of Bacillus subtilis L1-21
}

\author{
Yongmei Li ${ }^{1}$, Mengyuan Xia ${ }^{1,2}$, Pengbo He ${ }^{1}$, Qiaoming Yang ${ }^{1}$, Yixin Wu ${ }^{1,3}$, Pengfei He ${ }^{1}$, Ayesha Ahmed ${ }^{1}$, \\ Xiangsong Li ${ }^{1,3}$, Yuehu Wang ${ }^{2}$, Shahzad Munir ${ }^{1, *}$ and Yueqiu He ${ }^{1, *}$
}

1 State Key Laboratory for Conservation and Utilization of Bio-Resources in Yunnan, Yunnan Agricultural University, Kunming 650201, China; kala.111@163.com (Y.L.); xiamengyuan@mail.kib.cn (M.X.); pengbohe@126.com (P.H.); Yang2021090930@163.com (Q.Y.); WY68579@126.com (Y.W.); nanhudaozhu@163.com (P.H.); aisha_ahmed01@hotmail.com (A.A.); lixiangsongyn@163.com (X.L.)

2 Yunnan Key Laboratory for Fungal Diversity and Green Development, Kunming Institute of Botany, Chinese Academy of Sciences, Kunming 650201, China; wangyuehu@mail.kib.ac.cn

3 Faculty of Agronomy and Biotechnology, Yunnan Agricultural University, Kunming 650201, China

* Correspondence: shahzad_munir@ynau.edu.cn (S.M.); ynfh2007@163.com (Y.H.)

\section{check for} updates

Citation: Li, Y.; Xia, M.; He, P.; Yang, Q.; Wu, Y.; He, P.; Ahmed, A.; Li, X.; Wang, Y.; Munir, S.; et al. Developing Penicillium digitatum Management Strategies on Post-Harvest Citrus Fruits with Metabolic Components and Colonization of Bacillus subtilis L1-21. J. Fungi 2022, 8, 80. https:/ / doi.org/10.3390/jof8010080

Academic Editors: Samantha C. Karunarathna, Belle Damodara Shenoy, Patcharee Pripdeevech, Sumedha Madawala, Alvin M.C. Tang, Benjarong Karbowy-Thongbai, Asha Janadaree Dissanayake and Arun Kumar Dutta

Received: 22 December 2021

Accepted: 10 January 2022

Published: 14 January 2022

Publisher's Note: MDPI stays neutral with regard to jurisdictional claims in published maps and institutional affiliations.

Copyright: (c) 2022 by the authors. Licensee MDPI, Basel, Switzerland. This article is an open access article distributed under the terms and conditions of the Creative Commons Attribution (CC BY) license (https:/ / creativecommons.org/licenses/by/ $4.0 /)$.

\begin{abstract}
Citrus is among the most important plants in the fruit industry severely infected with pathogens. Citrus green mold caused by Penicillium digitatum is one of the most devastating diseases during post-harvest stages of citrus fruit. In this study, a potential endophyte Bacillus subtilis L1-21, isolated from healthy citrus plants, was assessed for its biocontrol activity against the pathogen $P$. digitatum. Based on an in vitro crosstalk assay, we suggested that B. subtilis L1-21 inhibits the pathogen with an inhibition zone of $3.51 \pm 0.08 \mathrm{~cm}$. Biocontrol efficacy was highest for the fermented culture filtrate of B. subtilis L1-21. Additionally, using GC-MS analysis, 13 compounds were detected in the extract of this endophyte. The culture filtrate in Landy medium could enlarge and deform pathogen spores and prevent them from developing into normal mycelium. Accordingly, the Landy culture filtrate of $B$. subtilis L1-21 was stable in the temperature range of $4-90{ }^{\circ} \mathrm{C}$ and $\mathrm{pH}$ of $3-11$. Further, MALDI-TOF-MS for B. subtilis L1-21 detected surfactin, fengycin, bacillaene and bacilysin as potential antifungal compounds. GFP-tagged B. subtilis L1-21 easily colonized in citrus fruit peel and pulp, suggesting its role in eliminating the fungal pathogen. Altogether, it is highly expected that the production of antifungal compounds, and the colonization potential of B. subtilis L1-21 are required against the post-harvest $P$. digitatum pathogen on citrus fruit.
\end{abstract}

Keywords: fungi; pathogen; Penicillium digitatum; Bacillus subtilis L1-21; LC-MS

\section{Introduction}

Citrus is a general term for citrus fruit trees, mainly including pomelo, mandarin, tangerine, lemon, sweet orange, grapefruit and lime [1]. The planting and yield of citrus fruit rank first in the fruit industry and give an idea of the importance of this fruit in international agricultural trade [2]. Citrus fruit is easily infected with various pathogens during postharvest storage and transportation, resulting in decay and deterioration, and economic losses, leading to adverse effects on the development of the citrus industry [3,4]. Postharvest disease in citrus fruit caused by Penicillium is one of the most severe diseases with losses of at least 10\% and, in severe cases, up to $90 \%$ [5,6]. Among them, the losses caused by the green mold of $P$. digitatum is the most devastating. The necrotic fungus gains entry in the fruit tissues through wounds and has a short life cycle of 3 to 5 days but produces a profound number of conidial spores that could initiate a new life cycle [7], spreading the infection exponentially. Thus, effective control measures are very important to avoid further loss. 
Traditional practices widely used for the management of Penicillium largely depend upon chemical fungicides such as pyrimethanil, imazalil, thiaben-dazole, prochloraz or different mixed formulations of these compounds [8]. However, the repetitive and excessive use of the same fungicides pose a threat to human and environmental health as well as the development of resistance in pathogensmake disease control near to impossible [9]. Thus, an effective and ecologically friendly method for post-harvest disease control is imperative. In this regard, potential bioagents have been reported for controlling citrus green mold and blue mold caused by Penicillium [10]. Additionally, the endophyte-medicated biocontrol of pathogens offers enhanced green agriculture and safe means for disease control, thus avoiding the adverse effects of chemical control [11,12]. It also showed positive effects on postharvest diseases and significantly maintained the fruit quality as well [13]. As it is generally regarded as safe (GRAS), biocontrol agents such as Bacillus spp. have been widely studied and reported for many years to manage plant diseases and improve plant survival [13-15]. In particular, B. amyloliquefaciens, B. subtilis, B. velezensis, B. megaterium, $B$. pumilus and $B$. cereus have effective antagonistic activity against a variety of plant pathogens, including fungi, bacteria and oomycetes [16,17]. Potential Bacillus spp. could control green mold caused by P. digitatum [18,19]. Other microorganisms for controlling citrus fruit green mold include Pseudomonas [20], Paenibacillus [21] and Aureobasidiuma [22].

Bacillus could control green mold through different interesting mechanisms and strategies. These mechanisms include induced resistance, wound colonization, competition with a pathogen for sites and nutrients, antifungal compounds, inhibition of spore germination, deformation of mycelia and disruption of the cell wall [19,23,24]. Numerous lipopeptide compounds from potential bacterial strains have been isolated, purified and identified, such as surfactin, fengycin and iturin $[25,26]$, macrolactin and bacillaene. These compounds are known to inhibit $P$. digitatum [24].

In our previous study, we reported that endophyte B. subtilis L1-21 regulates important metabolites in huanglongbing (HLB)-affected citrus plants [14]. However, the role of this endophyte was unknown in the citrus fruit during storage. Using the candidate citrus endophytic microbiome during citrus fruits storage could help in reducing the pathogen incidence and severe losses to the citrus industry. Therefore, the present study was aimed at isolating and identifying potential pathogens of citrus green mold, and to improve the biocontrol efficacy of endophyte B. subtilis L1-21. The colonization potential of this endophyte was revealed in detail during the pathogen interaction inside the citrus fruit. Furthermore, we elucidated the mode of action in conjunction with metabolic compounds produced by B. subtilis L1-21 to develop an efficient strategy for protection against citrus fruit green mold diseases.

\section{Materials and Methods}

\subsection{Bacterial Strains and Culture Conditions}

Bacillus subtilis L1-21 was previously isolated from healthy citrus plant [14]. The endophytic strain was stored at $-80{ }^{\circ} \mathrm{C}$ in $50 \%$ glycerol stock, and the pure culture was inoculated into nutrient broth (NB) for further use. The culture filtrate of B. subtilis L1-21 was prepared in Luria Bertani (LB) medium at $30^{\circ} \mathrm{C}$ at $160 \mathrm{rpm}$ for $16 \mathrm{~h}$, and $1 \%(v: v)$ was inoculated in the above medium at $160 \mathrm{rpm}$ at $30^{\circ} \mathrm{C}$. Samples were taken every day until the 4th day. After fermentation, the medium was centrifuged at 10,000 rpm for $15 \mathrm{~min}$ and then the supernatant was filtrated using $0.22 \mu \mathrm{m}$ filter paper. The green fluorescence protein (GFP) labelled B. subtilis L1-21 was obtained through transforming the vector pYC127 [27], hence named as B. subtilis L1-21-GFP.

\subsection{Fruit Materials}

Mandarin (Citrus reticulata cv. Shatangju) fruits were harvested from an orchard located in Guiling Guanxi Province, China. The citrus plants present in the orchard were not given any chemical treatment. The fruit brought to the laboratory were rinsed for $3 \mathrm{~min}$ with flowing water followed by surface sterilization with $2.5 \%$ of sodium hypochlorite for 
2 min, washed with distilled water, $75 \%$ of ethanol $(v / v)$ for $1 \mathrm{~min}$, washed three times with sterile distilled water, and air-dried at room temperature in laminar flow hood for further use.

\subsection{Isolation and Identification of Potential Penicillium Isolates}

The conidia from the diseased citrus fruit were picked with a sterilized wire loop on an ultra-clean workbench and cultured on potato dextrose agar (PDA) medium at $25 \pm 1{ }^{\circ} \mathrm{C}$ for $3 \mathrm{~d}$. After purification, the conidia were stored at $4{ }^{\circ} \mathrm{C}$ for a short period. In order to check the pathogenicity of isolate, spores were inoculated at the equator of citrus fruit with concentrations of $10^{3}$ spores $\mathrm{mL}^{-1}, 10^{4}$ spores $\mathrm{mL}^{-1}$ and $10^{5}$ spores $\mathrm{mL}^{-1}$, and kept at $25 \pm 1{ }^{\circ} \mathrm{C}$. The citrus fruits were observed for pathogenicity after $4 \mathrm{~d}$. Further, for molecular identification of the pathogenic fungus, the fungus stored at $4{ }^{\circ} \mathrm{C}$ was inoculated on PDA medium at $25 \pm 1{ }^{\circ} \mathrm{C}$ with a sterilized wire loop on an ultra-clean workbench and cultured for $3 \mathrm{~d}$ at $25 \pm 1{ }^{\circ} \mathrm{C}$ for DNA extraction. After that, the mycelia and spores were harvested, the slightly modified cetyl trimethylammonium bromide (CTAB) method was used to extract genomic DNA [28]. ITS1 (TCCGTAGGTGAACCTGCGG) and ITS4 (TCCTCCGCTTATTGATATGC) were used for identification. The PCR reaction conditions were as follows: pre-denaturation at $94{ }^{\circ} \mathrm{C}$ for $4.5 \mathrm{~min} ; 30$ cycles of $94{ }^{\circ} \mathrm{C}$ denaturation for $30 \mathrm{~s}, 56{ }^{\circ} \mathrm{C}$ annealing for $30 \mathrm{~s}, 72{ }^{\circ} \mathrm{C}$ extension for $45 \mathrm{~s}$, followed by a 10-min extension at $72{ }^{\circ} \mathrm{C}$. PCR products of targeted bands were sent to Kunming Qingke Biotechnology Co., LTD, China for sequencing. The obtained sequences were trimmed and submitted to the National Center for Biotechnology Information (NCBI). BLAST was performed to check for a homologous search against microbial genomes. In total, 9 sequences from the matched results were used to construct the phylogenetic tree of strain L1 with the software MEGA X.

\subsection{Cross-Talk Experiment between Fungal Pathogen and Potential Endophyte}

Culture of $B$. subtilis L1-21 was obtained on NB agar after $24 \mathrm{~h}$. Petri dishes $(9 \mathrm{~cm})$ containing $15 \mathrm{~mL}$ of PDA were prepared. In total, $100 \mu \mathrm{L}$ of pathogen suspension $\left(1.0 \times 10^{5}\right.$ spores $\left.\mathrm{mL}^{-1}\right)$ was applied to the PDA medium and kept for few minutes for drying [13]. B. subtilis L1-21 was inoculated at four symmetrical points $2.5 \mathrm{~cm}$ from the center for $2 \mathrm{~d}$ at $25 \pm 1^{\circ} \mathrm{C}$. After $2 \mathrm{~d}$, the diameter of the inhibition zone was measured accordingly.

\subsection{Biocontrol Efficacy Assay}

One puncture was made with a sterile tip at a 1-cm depth at the equator of citrus fruit. B. subtilis L1-21 cells and P. digitatum spores were suspended in a $0.85 \%$ sodium chloride solution. The punctures were inoculated with the following treatments: (i) control 1, $10 \mu \mathrm{L}$ of $P$. digitatum spore suspension $\left(1 \times 10^{4}\right.$ spores $\left.\mathrm{mL}^{-1}\right)$ and $10 \mu \mathrm{L}$ of $0.85 \%$ sodium chloride solution; control $2,10 \mu \mathrm{L}$ of $P$. digitatum spore suspension $\left(1 \times 10^{4}\right.$ spores $\left.\mathrm{mL}^{-1}\right)$ and $10 \mu \mathrm{L}$ of NB culture; (ii) $10 \mu \mathrm{L}$ of $P$. digitatum spore suspension $1 \times 10^{4}$ spores $\mathrm{mL}^{-1}$ ) and $10 \mu \mathrm{L}$ of B. subtilis L1-21 cell suspension (without culture filtrate, $1 \times 10^{8} \mathrm{CFU} \mathrm{mL}^{-1}$ ); (iii) $10 \mu \mathrm{L}$ of P. digitatum spore suspension and $10 \mu \mathrm{L}$ of $B$. subtilis L1-21 culture filtrate; and (iv) $10 \mu \mathrm{L}$ of P. digitatum spore suspension and $10 \mu \mathrm{L}$ of $B$. subtilis L1-21 fermentation (cell and culture filtrate). Control 1 was set for treatment (ii) and control 2 was set for treatment (iii) and (iv). Each replication consisted of 30 citrus fruits and each treatment consisted of three replications. The modified disease fruit grading standard was as following [29]: Grade 0, healthy; Grade 1, mold area $\leq 20 \%$; Grade 2, mold area $>20$ and $\leq 40 \%$; Grade 3, mold area $>40$ and $\leq 60 \%$; Grade 4, mold area $>60$ and $\leq 80 \%$; Grade 5, mold area $>80 \%$.

$$
\text { Disease index }=\frac{\sum(\text { Number of disease of fruit } \times \text { number of Grade })}{\text { Total number of fruit } \times \text { highest number of Grade }}
$$

Biocontrol efficacy $=\frac{\text { Disease index of control }- \text { disease index of treatment }}{\text { Disease index of control }} \times 100 \%$ 


\subsection{Identification of Bacillus Subtilis L1-21 Extracts Using GC-MS}

In order to prove how this B. subtilis L1-21 displayed a marked inhibitory effect against the pathogen, B. subtilis L1-21 was cultured in NB medium and incubated at $30^{\circ} \mathrm{C}$ and $160 \mathrm{rpm}$ for $4 \mathrm{~d}$. The cells were removed after centrifugation, $200 \mathrm{~mL}$ of supernatant was extracted with $200 \mathrm{~mL}$ of ethyl acetate 3 times, $600 \mathrm{~mL}$ of ethyl acetate was evaporated by rotation, and cells were finally dissolved in $4 \mathrm{~mL}$ of ethyl acetate. GC-MS analysis was operated using a gas chromatography (7890-5975c, Agilent, United States) equipped with DB-5MS (30 $\mathrm{m} \times 0.25 \mathrm{~mm} \times 0.25 \mu \mathrm{m})$ and a mass spectrometer (EI with replaceable horn). The temperature program was set at an initial temperature of $40{ }^{\circ} \mathrm{C}$ for $1 \mathrm{~min}$, and then increased to $130{ }^{\circ} \mathrm{C}$ at $10^{\circ} \mathrm{C} \mathrm{min}^{-1}$, maintained for $5 \mathrm{~min}$ and then increased to $230{ }^{\circ} \mathrm{C}$ at $8^{\circ} \mathrm{C} \mathrm{m^{-1 }}$, and maintained for $5 \mathrm{~min}$; in total, $30.5 \mathrm{~min}$. High-purity helium was used at a constant flow rate of $1 \mathrm{~mL} \mathrm{~min}^{-1}$. The mass spectrometer was equipped with a $70 \mathrm{eV}$ electron impact ionization (interface temperature of $280^{\circ} \mathrm{C}$, ion source temperature of $230{ }^{\circ} \mathrm{C}$ ) and a quadrupole analyzer. The ions were detected in the range of 50-600 $\mathrm{m} / \mathrm{z}$. Finally, results of mass spectra were analyzed using Chemistation software (Agilent, United States).

\subsection{Screening Medium for Producing Antifungal Substances}

$\mathrm{NB}$ medium, MT medium (peptone, $1 \mathrm{~g} \mathrm{~L}^{-1}$; glucose, $1 \mathrm{~g} \mathrm{~L}^{-1} ; \mathrm{CaCl}_{2}, 1 \mathrm{~g} \mathrm{~L}^{-1} ; \mathrm{K}_{2} \mathrm{HPO}_{4}$, $\left.1 \mathrm{~g} \mathrm{~L}^{-1} ; \mathrm{MgSO}_{4}, 0.2 \mathrm{~g} \mathrm{~L}^{-1} ; \mathrm{FeCl}_{3}, 0.01 \mathrm{~g} \mathrm{~L}^{-1} ; \mathrm{pH}=7.0\right), \mathrm{R}_{2} \mathrm{~A}$ medium, tryptic soya gar (TSA) medium, 10\% TSA medium and Landy medium were selected for screening. The culture filtrate of B. subtilis L1-21 was prepared in LB medium at $30^{\circ} \mathrm{C}$ and $160 \mathrm{~g}$ for $16 \mathrm{~h}$, and $1 \%$ (v:v) was inoculated in the above medium at $160 \mathrm{rpm}$ and $30^{\circ} \mathrm{C}$. Samples were taken every day until the 4 th $\mathrm{d}$. After fermentation, the medium was centrifuged at 10,000 rpm for $15 \mathrm{~min}$ and then the supernatant was filtrated through $0.22 \mu \mathrm{m}$ filter paper. After mixing $(1: 1, v / v)$ culture filtrate with PDA (filtration) containing $0.8 \%(w: v)$ agar, $50 \mu \mathrm{L}$ of the mixture was put onto the sterilized glass slide; $40 \mu \mathrm{L}$ of spore suspension $\left(10^{6}\right.$ spores $\left.\mathrm{mL}^{-1}\right)$ was added to the solidification drop, and was incubated at $25 \pm 1^{\circ} \mathrm{C}$; the spore germination was observed and counted after $32 \mathrm{~h}$. The medium without inoculating B. subtilis L1-21 was used as the control. Prochloraz was used as positive control with a concentration of $450 \mathrm{mg} / \mathrm{L}$ (Zhejiang Tianfeng Biological Science Co., Ltd. China). The spore germination was observed under microscope (ZEISS) and the spore germination rate was calculated. More than 200 spores were counted for each treatment and three replications were used for each. The morphology of spores was observed using scanning electron microscope (ZEISS Sigma 300, Germany; Turbo Freeze Dryer with Turbo Freeze Dryer with liquid nitrogen, Quorum, UK; Kunming Institute of Botany, Chinese Academy of Science).

$$
\text { Germination rate }=\frac{\text { Number of germination spore }}{\text { Total number of spore }}
$$

$$
\text { Inhibition rate }=\frac{\text { Germination rate of control }- \text { germination rate of treatment }}{\text { Germination rate of control }}
$$

\subsection{Antifungal Stability of Bacillus Subtilis L1-21 Culture Filtrate}

Temperature tolerance of $B$. subtilis L1-21 culture filtrate was checked using $500 \mu \mathrm{L}$ of filtrate in the range of 50,60, 70, 80 and $90{ }^{\circ} \mathrm{C}$ in a water bath for $30 \mathrm{~min}$. Autoclave was used at 100 and $121^{\circ} \mathrm{C}$ for $30 \mathrm{~min}$ and culture was brought to room temperature for bioassay experiments. Culture filtrate was kept at $4{ }^{\circ} \mathrm{C}$ for $7 \mathrm{~d}$ for a low temperature tolerance bioassay. Further, UV light treatment was given by exposing $500 \mu \mathrm{L}$ of culture filtrate in a Petri dish (6 cm, without cover) to 365-nanometer UV light for 15, 30, 45, 60 and $121 \mathrm{~min}$ at a distance of $30 \mathrm{~cm}$, and the experiment was repeated three times. In addition, L1-21 culture filtrate was adjusted to $\mathrm{pH} 1-12$ using $0.5 \mathrm{M} \mathrm{HCl}$ and $\mathrm{NaOH}$ and placed at room temperature for $24 \mathrm{~h}$, followed by an adjustment of $\mathrm{pH} 7$ for bioassay, and the $\mathrm{pH} 6$ served as the control group. Each treatment consisted of three replicates. After all the above treatments, effects of culture filtrate on spore germination rate of $P$. digitatum were determined to evaluate the stability of culture filtrate. 


\subsection{Characterization of the Antifungal Compounds Using LC-MS}

The antifungal compounds were detected using LC-MS. Culture filtrate of B. subtilis L1-21 grown in $200 \mathrm{~mL}$ of Landy was dried at $50{ }^{\circ} \mathrm{C}$, followed by an addition of $4 \mathrm{~mL}$ of methanol to dissolve the compounds. Chromatographic separation was carried out using a column (AQC18 column, $5.0 \mu \mathrm{m} 4.6 \times 250 \mathrm{~mm}, 5 \mu \mathrm{m}$, Welch Ultimate, China) with a flow rate of $1 \mathrm{~mL} \mathrm{~min}^{-1}$. A mobile phase consisting of $0.5 \%(v / v)$ trifluoroacetic acid (TFA) (A) and methanol (B) was used. The following linear gradient elution was used: $5 \%$ methanol at $0 \mathrm{~min}$, increased to $100 \%$, kept at $100 \%$ methanol from 60 to $70 \mathrm{~min}$. The UFLC-MS-IT-TOF apparatus and method were used as performed previously by Li et al. [30]. The ions were detected in the range of $1-1000 \mathrm{~m} / \mathrm{z}$ and $800-2000 \mathrm{~m} / \mathrm{z}$, respectively.

\subsection{Colonization of GFP-Tagged Endophytic Strain}

GFP-tagged B. subtilis L1-21 was put on shaking in NB medium (with chloramphenicol $10 \mu \mathrm{g} \mathrm{mL}^{-1}$ ) at $160 \mathrm{rpm}$ with $37^{\circ} \mathrm{C}$ for $2 \mathrm{~d}$. The fruit were soaked in GFP-L1-21 $\left(1 \times 10^{8} \mathrm{CFU} \mathrm{mL}{ }^{-1}\right)$ for $30 \mathrm{~min}$ and kept at $25 \pm 1{ }^{\circ} \mathrm{C}$. Samples were taken at 1, 3, 5 and $7 \mathrm{~d}$ with three replicates in each treatment. After surface sterilization, $1 \mathrm{~g}$ of the fruit peel and pulp was ground and $9 \mathrm{~mL}$ of sterilized $0.85 \%(w / v)$ sodium hypochlorite was added. The $100-\mu \mathrm{L}$ tissue solution was inoculated on a chloramphenicol $\left(10 \mu \mathrm{g} \mathrm{mL}^{-1}\right) \mathrm{NB}$ plate and incubated at $37^{\circ} \mathrm{C}$ for $24 \mathrm{~h}$; the number of GFP colonies was counted. The colonization ability was further validated using a scanning electron microscope. In this experiment, one puncture was made with a sterile tip at a $1 \mathrm{~cm}$ depth at the equator of citrus fruit. The experiment was carried out in the following order: Control (CK) for 12 and $24 \mathrm{~h} ; 10 \mu \mathrm{L}$ of B. subtilis L1-21 cell suspension (without culture filtrate, $1 \times 10^{8} \mathrm{CFU} \mathrm{mL}^{-1}$ ) for 12 and $24 \mathrm{~h} ; 10 \mu \mathrm{L}$ of $P$. digitatum spore suspension for $24 \mathrm{~h} ; 10 \mu \mathrm{L}$ of $P$. digitatum spore suspension $\left(1 \times 10^{4}\right.$ spores $\left.\mathrm{mL}^{-1}\right)$ and $10 \mu \mathrm{L}$ of $B$. subtilis L1-21 cell suspension for 12 and $24 \mathrm{~h}$. The fruits were kept at $25 \pm 1{ }^{\circ} \mathrm{C}$. The wound of citrus fruit was cut and then observed using a scanning electron microscope at 12 and $24 \mathrm{~h}$.

\subsection{Data Analysis}

All data were statistically analyzed using SPSS version 22 (SPSS Inc., Chicago, IL, USA) using a one-way analysis of variance (ANOVA). Duncan's multiple range test was applied to determine the significant difference at $p<0.05$. All data acquired from the repeated experiments were expressed using the mean \pm standard deviation.

\section{Results}

\subsection{Morphological and Molecular Identification}

The macro and microscopic observations of the fungal isolate from citrus fruit confirmed that it belongs to genus Penicillium with depictions of conidiophores and spores (Figure 1A,B). The partial 18S rRNA gene sequence was deposited to NCBI and a GenBank accession number was assigned (MZ881937). The results of the identity analysis of the sequences confirmed that they belonged to Penicillium digitatum (Figure 1C). P. digitatum L1 $10^{3}, 10^{4}$ and $10^{5}$ spores $\mathrm{mL}^{-1}$ upon inoculation into healthy citrus fruit caused fruit rot and green mold (Figure 1D).

\subsection{In Vitro Biocontrol Efficacy and Effects of Bacillus Subtilis L1-21 on Penicillium Digitatum}

Bacillus subtilis L1-21 showed a potential inhibition effect on the mycelial growth of P. digitatum during co-culture assays on PDA (Figure 2). The diameter of each inhibition zone was observed as $3.51 \pm 0.08 \mathrm{~cm}$. After inoculating P. digitatum for $3 \mathrm{~d}$ in PDA medium, the biocontrol efficacies of fermentation in NB medium (cell and culture filtrate) treatment, cell suspension and culture filtrate treatment were $98.15 \pm 3.21 \%, 54.47 \pm 12.33 \%$ and $85.10 \pm 13.45 \%$, respectively (Figures 3 and 4 ). After $7 \mathrm{~d}$, the biocontrol efficacy of the fermentation treatment (cell and culture filtrate) of B. subtilis L1-21 appeared to be the highest, followed by the cell suspension of B. subtilis L1-21, and the culture filtrate 
treatment was recorded as the lowest. The results suggested that the biocontrol efficacy of all three treatments decreased over time.
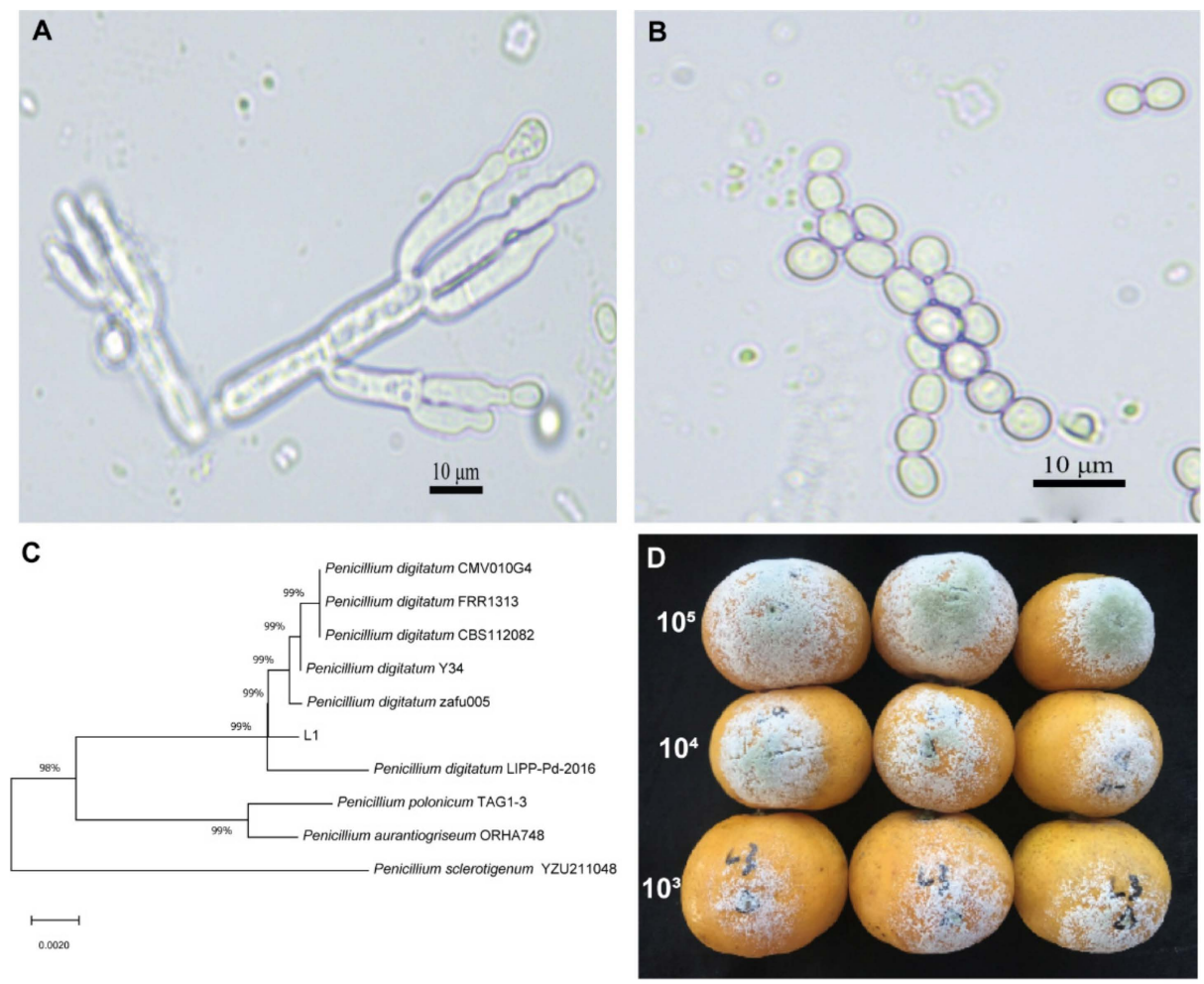

Figure 1. (A,B) Morphological characteristics of Penicillium digitatum strain L1 with conidiophores and spores. (C) Molecular phylogenetic tree of partial 18S rRNA gene sequence of $P$. digitatum L1. (D) Pathogenicity of $P$. digitatum L1 spores at different concentrations on citrus fruits.
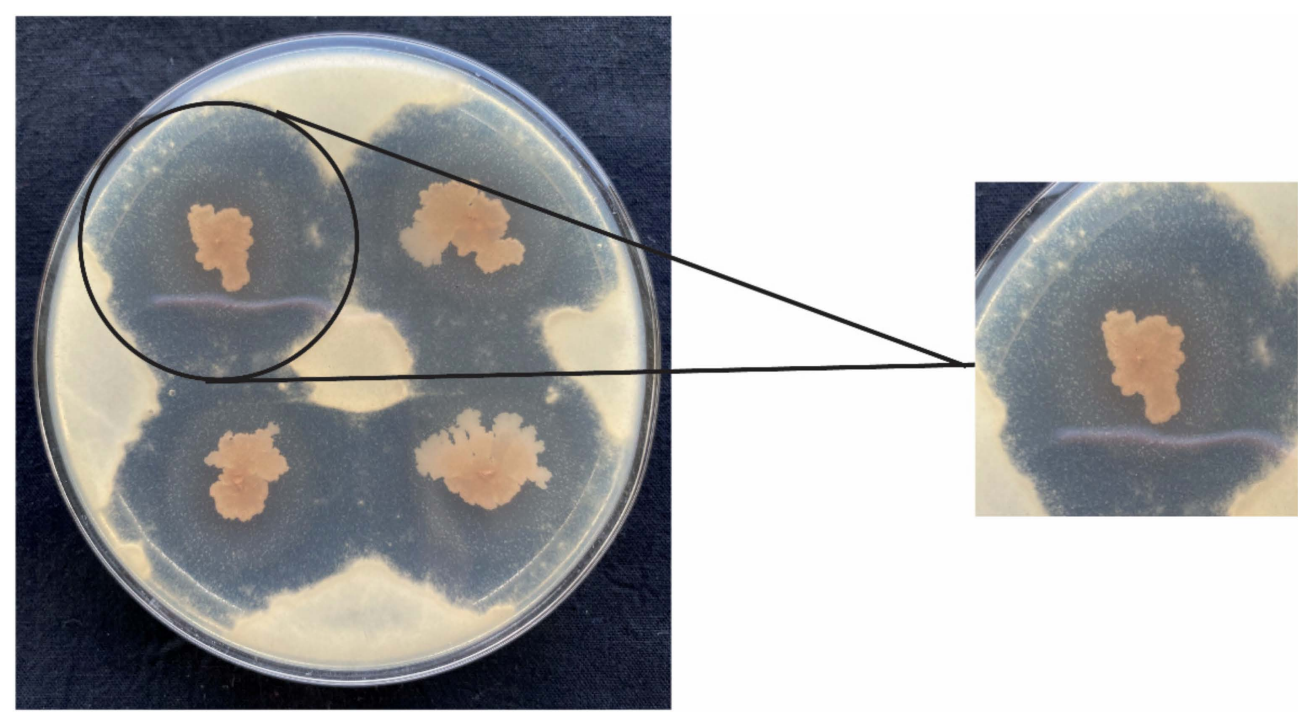

Figure 2. In vitro crosstalk assay between pathogen and Bacillus subtilis L1-21. The hollow zones around pink colonies display growth inhibition of pathogen by endophyte L1-21. 


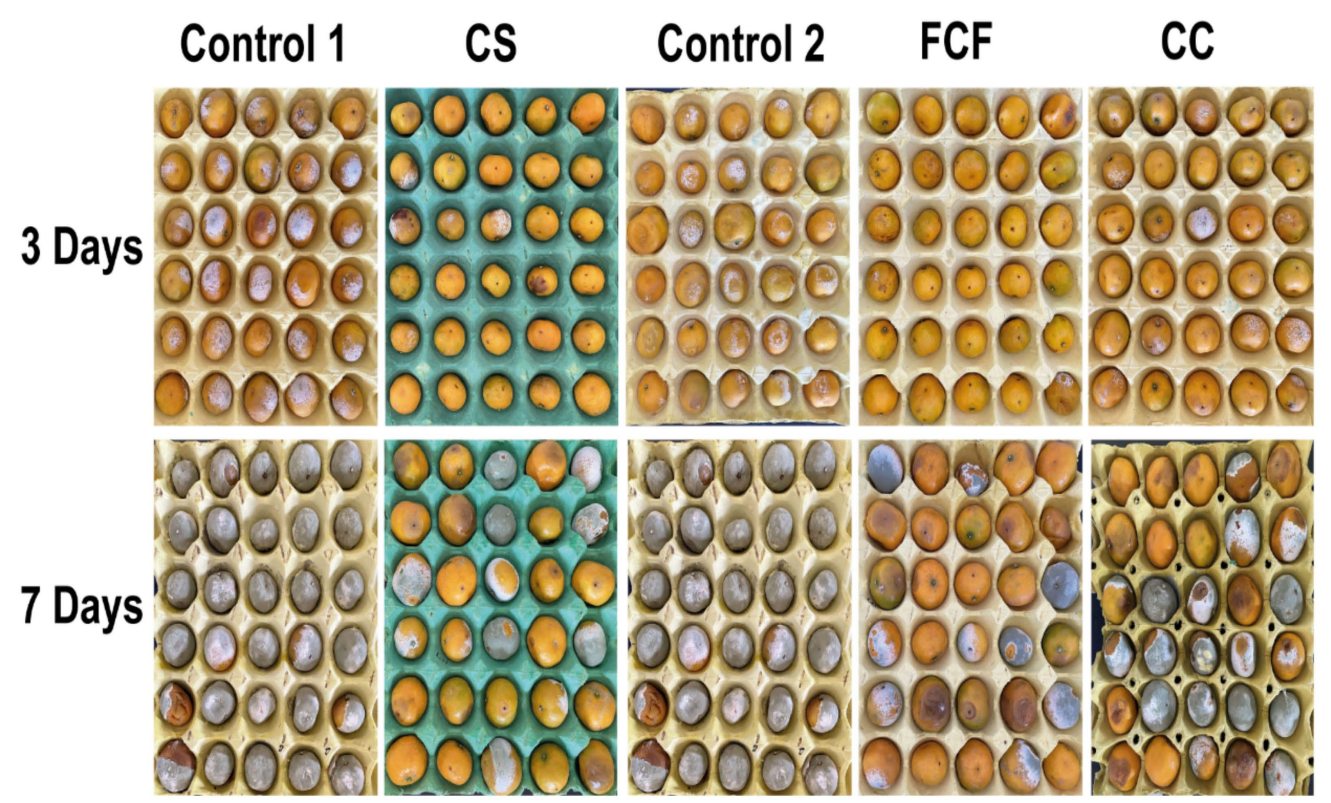

Figure 3. Biocontrol efficacy after 3 and $7 \mathrm{~d}$ have a significant inhibition of pathogens on citrus fruit. The treatments show a marked difference compared with the control, where the control effect is better at 3 d. CS, cell suspension; FCF, fermented cell filtrate; CC, culture filtrate; Control 1, water; Control 2, NB media.

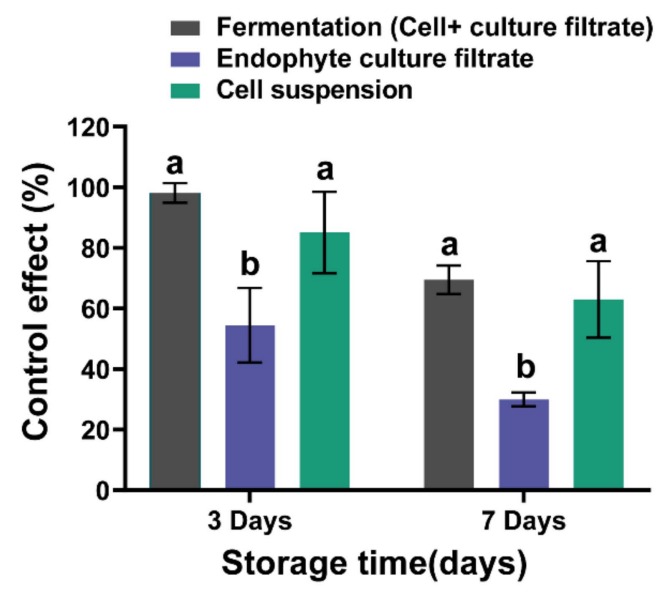

Figure 4. In vivo effects of different treatments of Bacillus subtilis L1-21 on citrus fruit. Different letters indicated a significant difference within the same time point according to the Duncan's multiple range test $(p<0.05)$.

\subsection{Extraction of Antifungal Compounds of Bacillus Subtilis L1-21 Using GC-MS}

A total of 44 peaks were detected using GC-MS, when the purified extract from supernatant of NB medium filtrate was loaded into the GC-MS for analysis (Figure S1). We identified 13 compounds (Figure 5 ) with a quality match of $85 \%$ minimum (Table 1 ), including 2-butenoic acid, 3-methyl-, phenol, phenylethyl alcohol, dodecane, benzofuran, 2,3dihydro-, benzeneacetic acid, tetradecane, hexadecane, Z-11-tetradecenoic acid, pyrrolo[1,2a]pyrazine-1,4-dione, hexahydro-3-(phenylmethyl)-, 1,2-benzenedicarboxylic acid, bis(2methylpropyl) ester, $\mathrm{n}$-Hexadecanoic acid and octadecanoic acid. Among them, the highest relative content was pyrrolo[1,2-a]pyrazine-1,4-dione, hexahydro-3-(phenylmethyl)- . 


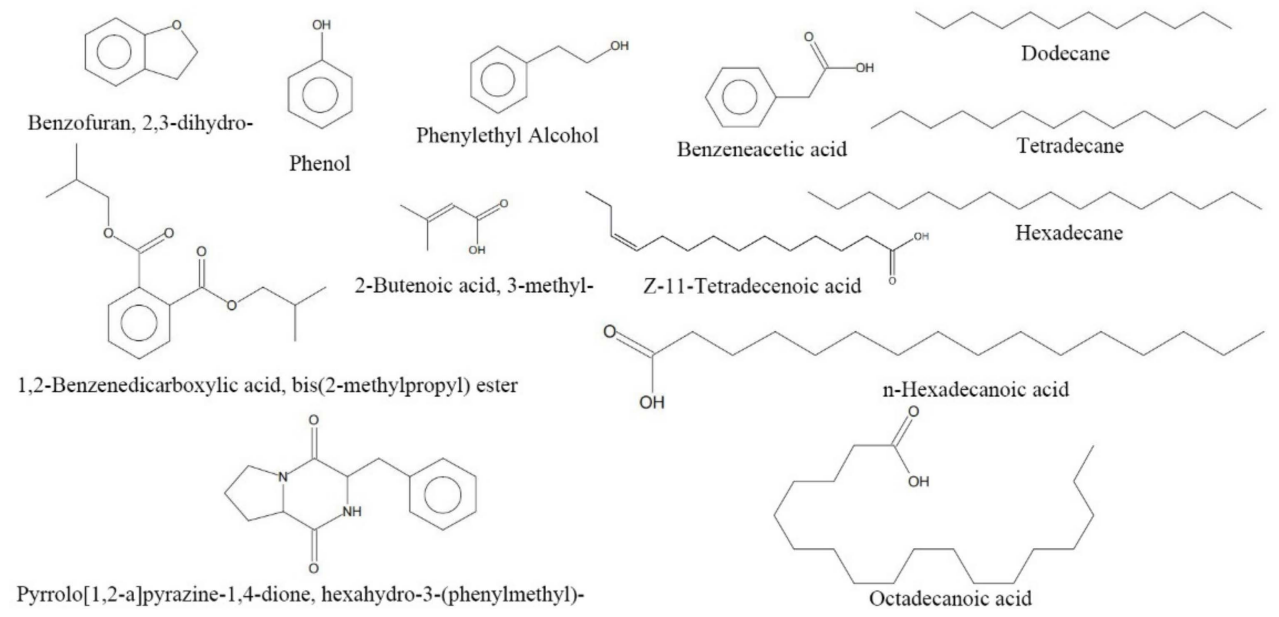

Figure 5. Chemical structures of the identified compounds from ethyl acetate extracts of Bacillus subtilis L1-21 using GC-MS.

Table 1. Components of ethyl acetate extract from Bacillus subtilis L1-21 by using GC-MS analysis.

\begin{tabular}{|c|c|c|c|c|c|c|}
\hline No & $\begin{array}{l}\text { Retention } \\
\text { Index }\end{array}$ & Compound & Exact Mass & Formula & $Q^{a}(\%)$ & $\begin{array}{c}\text { Relative } \\
\text { Content }(\%) b\end{array}$ \\
\hline 1 & 6.387 & 2-Butenoic acid, 3-methyl- & 100.05 & $\mathrm{C}_{5} \mathrm{H}_{8} \mathrm{O}_{2}$ & 97 & 0.21 \\
\hline 2 & 7.125 & Phenol & 94.04 & $\mathrm{C}_{6} \mathrm{H}_{6} \mathrm{O}$ & 91 & 0.43 \\
\hline 3 & 9.185 & Phenylethyl Alcohol & 122.07 & $\mathrm{C}_{8} \mathrm{H}_{10} \mathrm{O}$ & 87 & 0.15 \\
\hline 4 & 10.455 & Dodecane & 170.20 & $\mathrm{C}_{12} \mathrm{H}_{26}$ & 97 & 0.14 \\
\hline 5 & 10.873 & Benzofuran, 2,3-dihydro- & 120.06 & $\mathrm{C}_{8} \mathrm{H}_{8} \mathrm{O}$ & 90 & 0.2 \\
\hline 6 & 11.514 & Benzeneacetic acid & 136.05 & $\mathrm{C}_{8} \mathrm{H}_{8} \mathrm{O}_{2}$ & 94 & 0.53 \\
\hline 7 & 15.388 & Tetradecane & 198.24 & $\mathrm{C}_{14} \mathrm{H}_{30}$ & 98 & 1.15 \\
\hline 8 & 20.400 & Hexadecane & 226.27 & $\mathrm{C}_{16} \mathrm{H}_{34}$ & 98 & 0.49 \\
\hline 9 & 22.689 & Z-11-Tetradecenoic acid & 226.19 & $\mathrm{C}_{14} \mathrm{H}_{26} \mathrm{O}_{2}$ & 91 & 0.21 \\
\hline 10 & $\begin{array}{l}23.645 \\
25.676 \\
25.756\end{array}$ & $\begin{array}{l}\text { Pyrrolo[1,2-a]pyrazine-1,4-dione, } \\
\text { hexahydro-3-(phenylmethyl)- }\end{array}$ & 244.12 & $\mathrm{C}_{14} \mathrm{H}_{16} \mathrm{~N}_{2} \mathrm{O}_{2}$ & $\begin{array}{l}94 \\
95 \\
99\end{array}$ & $\begin{array}{l}2.80 \\
6.60 \\
3.67\end{array}$ \\
\hline 11 & 24.646 & $\begin{array}{l}\text { 1,2-Benzenedicarboxylic acid, bis } \\
\text { (2-methylpropyl) ester }\end{array}$ & 278.15 & $\mathrm{C}_{16} \mathrm{H}_{22} \mathrm{O}_{4}$ & 91 & 3.62 \\
\hline 12 & 26.071 & n-Hexadecanoic acid & 256.24 & $\mathrm{C}_{16} \mathrm{H}_{32} \mathrm{O}_{2}$ & 98 & 0.63 \\
\hline 13 & 28.617 & Octadecanoic acid & 284.27 & $\mathrm{C}_{18} \mathrm{H}_{36} \mathrm{O}_{2}$ & 98 & 0.33 \\
\hline
\end{tabular}

${ }^{\mathrm{a}} \mathrm{Q}$ for match quality. ${ }^{\mathrm{b}}$ peak area relative to the total peak area.

\subsection{Culture Filtrate of Endophyte Bacillus Subtilis L1-21 on Spore Germination}

Six culture filtrates of $B$. subtilis L1-21 were tested to assess the difference in inhibition activity on spore germination. However, the highest inhibition was recorded for the culture filtrate of Landy medium (Table 2), but there were differences in the spore morphology. The low concentration of Landy culture filtrate could enlarge and deform spores; even with a small amount of spore germination, spores could not develop into mycelia normally (Figure 6). The high concentration of B. subtilis L1-21 culture filtrate in Landy medium could inhibit spore germination with the morphology of spores similar to the treatment of fungicide prochloraz for $72 \mathrm{~h}$ (Figure 6). 
Table 2. Effect of Bacillus subtilis L1-21 culture filtrate on spore germination of pathogen.

\begin{tabular}{ccccc}
\hline \multirow{2}{*}{$\begin{array}{c}\text { Culture } \\
\text { Medium Type }\end{array}$} & \multicolumn{4}{c}{ Inhibition Rate (\%) } \\
\cline { 2 - 5 } & $\mathbf{2 4}$ & $\mathbf{4 8}$ Culture Time (h) & $\mathbf{9 6}$ \\
\hline NB & $93.98 \pm 1.34 \mathrm{a}$ & $95.39 \pm 1.31 \mathrm{ab}$ & $94.02 \pm 0.94 \mathrm{a}$ & $91.38 \pm 0.91 \mathrm{c}$ a \\
Landy & $95.61 \pm 0.85 \mathrm{a}$ & $94.62 \pm 0.48 \mathrm{ab}$ & $98.32 \pm 0.33 \mathrm{a}$ & $96.57 \pm 0.30 \mathrm{ab}$ \\
TSA & $6.00 \pm 1.53 \mathrm{c}$ & $2.25 \pm 1.68 \mathrm{~d}$ & $5.22 \pm 0.94 \mathrm{~d}$ & $4.26 \pm 0.96 \mathrm{e}$ \\
$10 \%$ TSA & $38.86 \pm 7.13 \mathrm{~b}$ & $66.70 \pm 3.32 \mathrm{c}$ & $36.32 \pm 5.88 \mathrm{c}$ & $48.09 \pm 3.35 \mathrm{~d}$ \\
$\mathrm{R}_{2} \mathrm{~A}$ & $38.92 \pm 6.35 \mathrm{~b}$ & $90.09 \pm 1.24 \mathrm{~b}$ & $87.16 \pm 1.08 \mathrm{a}$ & $92.57 \pm 2.53 \mathrm{bc}$ \\
MT & $94.92 \pm 1.21 \mathrm{a}$ & $93.74 \pm 0.37 \mathrm{ab}$ & $76.15 \pm 4.94 \mathrm{~b}$ & $87.66 \pm 0.84 \mathrm{c}$ \\
Prochloraz (Positive & $98.34 \pm 0.55 \mathrm{a}$ & $98.34 \pm 0.55 \mathrm{a}$ & $98.34 \pm 0.55 \mathrm{a}$ & $98.34 \pm 0.55 \mathrm{a}$ \\
Control) & & & & \\
\hline
\end{tabular}

${ }^{\mathrm{a}}$ Different letters indicate the significant differences $(p<0.05)$.
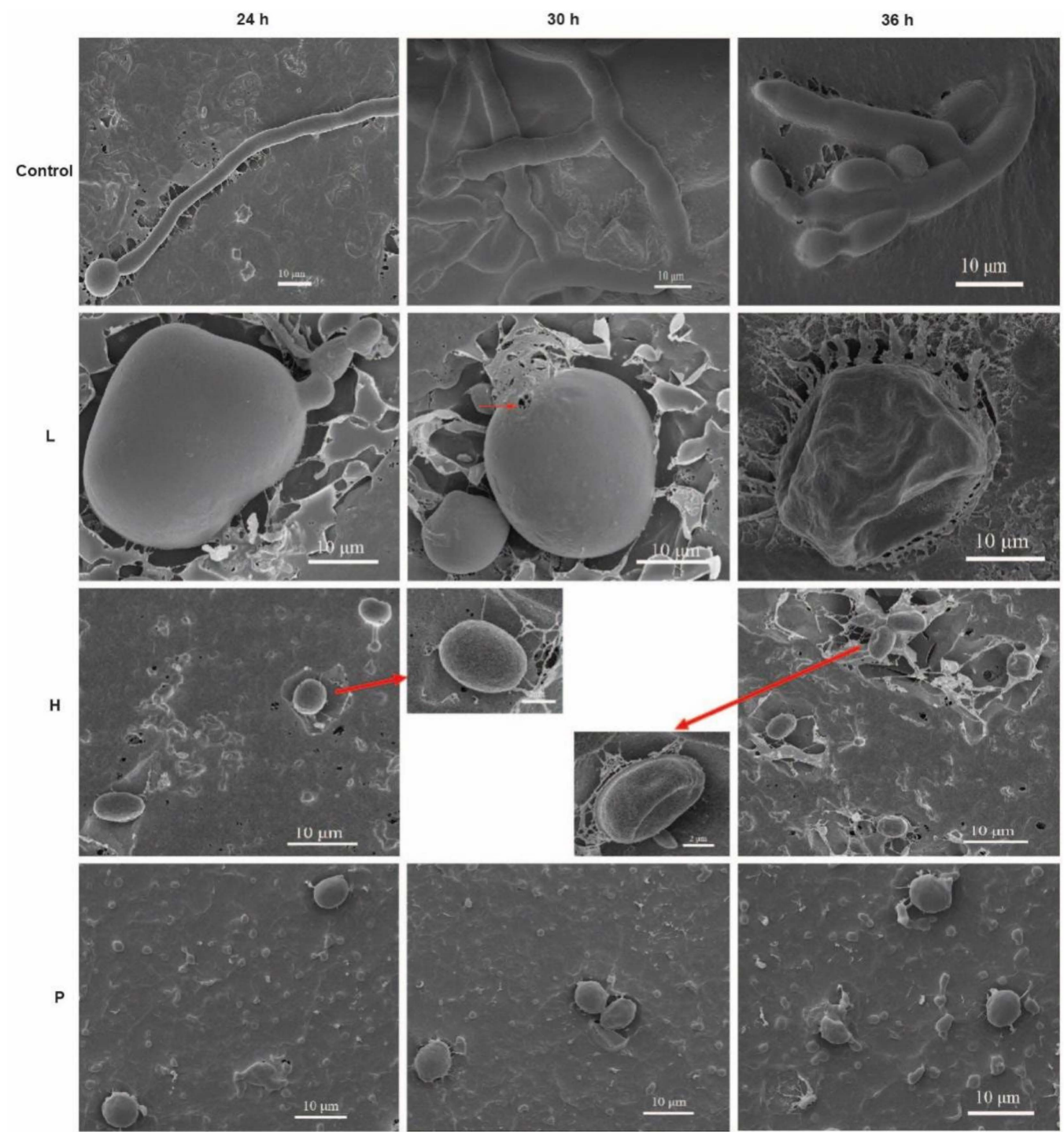

Figure 6. Bacillus subtilis L1-21 culture filtrate were tested against the pathogen. Spore germination and morphology were observed under a scanning electron microscope. Deformed spores were present in the presence of culture filtrate of B. subtilis L1-21. L means low concentration (5-fold dilution from higher concentration) of $B$. subtilis L1-21 Landy culture filtrate, $\mathrm{H}$ means high concentration of B. subtilis L1-21 Landy culture filtrate (B. subtilis L1-21 was cultured in Landy medium for $72 \mathrm{~h}$ ), P means prochloraz (Fungicide widely used in China for controlling citrus fruit green mold) (positive control).

\subsection{Stability of Bacillus Subtilis L1-21 Culture Filtrate under Different Conditions}

The stability of B. subtilis L1-21 culture filtrate present in Landy medium was checked in the presence of different temperature ranges. No significant difference was detected 
ranging from $40-90{ }^{\circ} \mathrm{C}$, but the inhibition rate of the endophyte was reduced at a temperature of 100 or $121^{\circ} \mathrm{C}$. Treatment for $30 \mathrm{~min}$ at $121{ }^{\circ} \mathrm{C}$ decreased the inhibition rate to $73.20 \%$ (Figure 7A). Except for $\mathrm{pH}$ treatments 2 and 12, the antifungal activity of the B. subtilis L1-21 culture filtrate could be kept or under strong-acid or strong-base treatment. The $\mathrm{pH} 2$ treatment resulted in a decrease inhibition rate to $83.63 \%$. Additionally, there was no significant difference among the different times of UV radiation from 15 to $120 \mathrm{~min}$ (Figure 7B). The effect of temperature on the antifungal activity of the B. subtilis L1-21 culture filtrate was stronger than that of $\mathrm{pH}$ or UV treatment when inhibition rates are concerned.
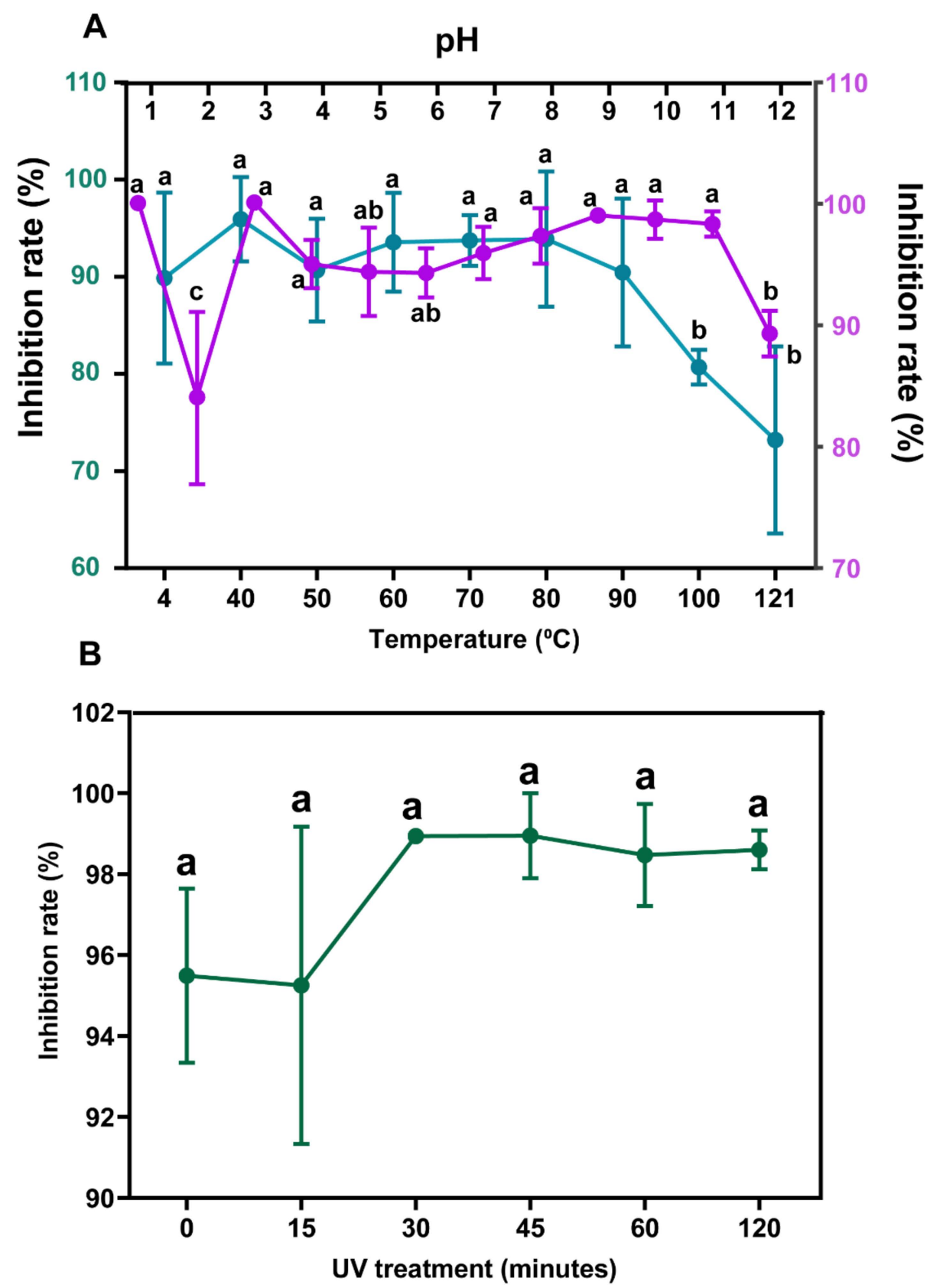

Figure 7. (A) Stability of Bacillus subtilis L1-21 in the presence of different temperatures and $\mathrm{pH}$ treatments. (B) UV effect on B. subtilis L1-21. Different letters on top indicate the significant differences $(p<0.05)$ over increasing temperature, $\mathrm{pH}$ and time. 
3.6. Characterization of Antifungal Compounds from Endophyte Bacillus Subtilis L1-21 Using LC-MS

The mass spectrometry data detected using MALDI-TOF-MS were analyzed and compared with the published research reported Bacillus metabolite and database Norine; we detected surfactin, fengycin, bacillaene and bacilysin in the Landy culture filtrate of B. subtilis L1-21 (Table 3; Figure 8). The sodiated molecules $[\mathrm{M}+\mathrm{Na}]^{+}$at $m / z 1030.58$, 1044.66, 1058.66, 1072.67 and 1086.71 were selected as precursor ions for further ESI-MS/MS analyses (Figures S2-S4). The ions at $m / z 392$ and 320 corresponded to ion formations $[\mathrm{Leu}-\mathrm{Leu}-\mathrm{Asp}+\mathrm{Na}+\mathrm{CO}]^{+}$and $[\mathrm{Leu}-\mathrm{Leu}-\mathrm{Val}+\mathrm{Na}-\mathrm{CO}]^{+}$. The ions at $m / z$ 707, 594, 481 and 463 matched ion formations [M + Na-SC-Glu] ${ }^{+},[\mathrm{M}+\mathrm{Na}-\mathrm{SC}-\mathrm{Glu}-\mathrm{Leu}]^{+},[\mathrm{M}+$ $\mathrm{Na}-\mathrm{SC}-\mathrm{Glu}-\mathrm{Leu}-\mathrm{Leu}]^{+}$and $\left[\mathrm{M}+\mathrm{Na}-\mathrm{SC}-\mathrm{Glu}-\mathrm{Leu}-\mathrm{Leu}-\mathrm{H}_{2} \mathrm{O}\right]^{+}$, respectively. SC refers to the $\beta-\mathrm{OH}$-fatty acid side chain. According to these regular ion formations, the amino acid sequence could be deduced as Glu-Leu-Leu-Val-Asp-Leu-Leu. Finally, the sodiated molecules $[\mathrm{M}+\mathrm{Na}]^{+}$at $m / z$ 1030.58, 1044.66, 1058.66, 1072.67 and 1086.71 were identified as $C_{13}$ surfactin $A, C_{14}$ surfactin $A, C_{15}$ surfactin $A, C_{16}$ surfactin $A$ and $C_{17}$ surfactin $A$, respectively (Table 3; Figure S5). The protonated molecules $[\mathrm{M}+\mathrm{H}]^{+}$at $m / z 1449.95$, $1463.97,1477.95,1491.98$ and 1505.99 were selected as precursor ions for further ESI-MS/MS analyses (Figure S6A-E). The ions at $\mathrm{m} / \mathrm{z}$ 1080, 966 and 896 corresponding to ion formations $\left[b_{2}\right]^{+},\left[b_{3}\right]^{+}$and $\left[c_{1}\right]^{+}$, respectively, were the characteristic fragment ions of fengycin $A$ (Figure S6F). The ions at $m / z$ 1108, 994 and 896 were the characteristic fragment ions of fengycin B (Figure S6F). In addition, the ions at $m / z$ 1094, 980 and 896 corresponding to ion formations $\left[b_{2}\right]^{+},\left[b_{3}\right]^{+}$and $\left[c_{1}\right]^{+}$, respectively, were the characteristic fragment ions of fengycin C (Figure S6F). The protonated molecules $[\mathrm{M}+\mathrm{H}]^{+}$at $m / z 1449.95,1463.97$, $1477.95,1491.98$ and 1505.99 were deduced as $C_{15}$ fengycin $A, C_{16}$ fengycin $A, C_{16}$ fengycin $C, C_{16}$ fengycin $B$ and $C_{17}$ fengycin $B$, respectively (Table 3: Figure S6).

Table 3. Antifungal components of Landy culture filtrate from Bacillus subtilis L1-21 by using LCMS analysis.

\begin{tabular}{|c|c|c|c|c|c|c|}
\hline \multirow{2}{*}{ Metabolite } & \multirow{2}{*}{$\frac{\text { Retention Index }}{(\min )}$} & \multicolumn{2}{|c|}{ Mass Peak, $m / z$} & \multirow{2}{*}{$\begin{array}{l}\text { Characteristic } \\
\text { Fragment Ions }\end{array}$} & \multirow{2}{*}{$\mathbf{M W}^{\mathrm{a}}$} & \multirow{2}{*}{ Assignment } \\
\hline & & {$[\mathrm{M}+\mathrm{H}]^{+}$} & {$[\mathrm{M}+\mathrm{Na}]^{+}$} & & & \\
\hline Bacilysin & 7.652 & - & 293.71 & - & 270.2 & Bacilysin \\
\hline Bacillaene & 17.567 & 581.78 & - & - & 580.4 & Bacillaene \\
\hline \multirow{5}{*}{ Fengycin } & 52.680 & 1449.95 & - & $1080,966,896$ & 1448.8 & $\mathrm{C}_{15}$ fengycin $\mathrm{A}$ \\
\hline & $50.638-51.103$ & 1463.97 & - & $1080,966,896$ & 1462.8 & $\mathrm{C}_{16}$ fengycin $\mathrm{A}$ \\
\hline & 51.257 & 1477.95 & - & $1094,980,896$ & 1477.8 & $\mathrm{C}_{16}$ fengycinC \\
\hline & 51.407 & 1491.98 & - & $1108,994,896$ & 1491.8 & $\mathrm{C}_{16}$ fengycin $\mathrm{B}$ \\
\hline & 52.377 & 1505.99 & - & $1108,994,896$ & 1504.8 & $C_{17}$ fengycin $B$ \\
\hline \multirow{5}{*}{ Surfactin } & $60.078-60.490$ & - & 1030.58 & $707,594,481$ & 1007.7 & $\mathrm{C}_{13}$ surfactin $\mathrm{A}$ \\
\hline & $60.933-62.042$ & - & 1044.66 & $707,594,481$ & 1021.7 & $\mathrm{C}_{14}$ surfactin $\mathrm{A}$ \\
\hline & $61.503-62.200$ & - & 1058.66 & $707,594,481$ & 1035.7 & $C_{15}$ surfactin $A$ \\
\hline & $61.978-62.453$ & - & 1072.67 & $707,594,481$ & 1049.7 & $\mathrm{C}_{16}$ surfactin $\mathrm{A}$ \\
\hline & 63.087 & - & 1086.71 & $707,594,481$ & 1063.7 & $\mathrm{C}_{17}$ surfactin $\mathrm{A}$ \\
\hline
\end{tabular}

${ }^{\mathrm{a}} \mathrm{MW}=$ molecular weight. 

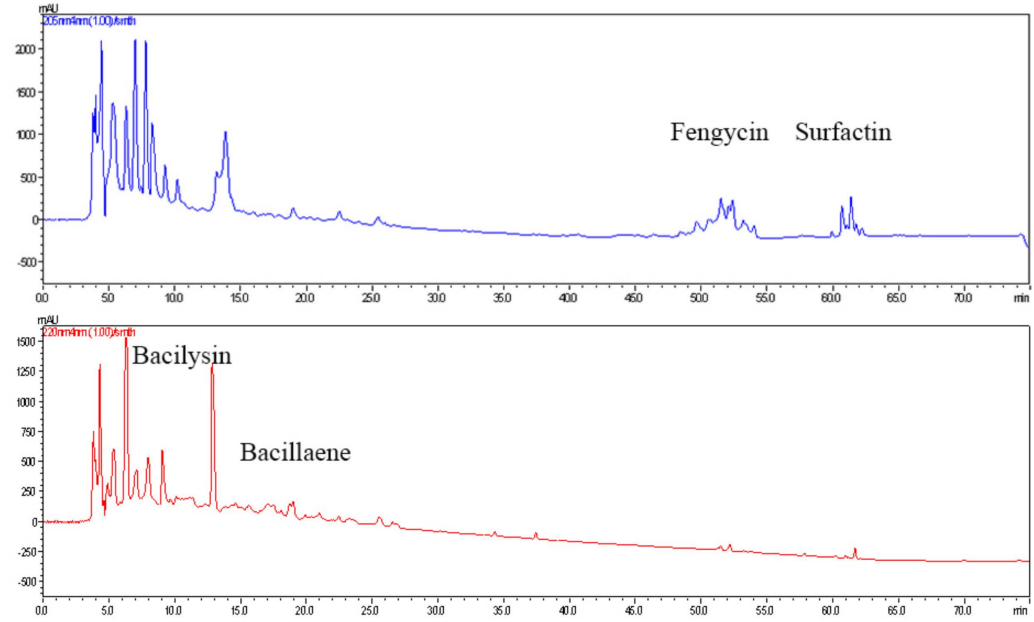

Figure 8. Ultra-performance liquid chromatography chromatograms of antifungal compounds produced by Bacillus subtilis L1-21.

\subsection{The Colonization Ability of Bacillus Subtilis L1-21}

Our results suggested that endophyte $B$. subtilis L1-21 could colonize in citrus fruit peel and pulp. The number of colonization was found to be highest after $3 \mathrm{~d}$ in both peel and pulp (Figure 9). The quantity of colonizers was higher in the peel than in the pulp. Our scanning electron microscopy results showed that B. subtilis L1-21 not only colonized inside the citrus fruit, but co-inoculation through wounds on pathogen $P$. digitatum mycelium showed that compared to the control (Figure 10A), it can easily colonize on the pathogen after $24 \mathrm{~h}$, as occupying significant space (Figure 10B) further suppressed the pathogen spread. As shown in Figure 10C, the pathogen spores grow normally in the absence of B. subtilis L1-21, but the inoculation of this endophyte displayed marked deformation of pathogen spores after $24 \mathrm{~h}$ (Figure 10D). Our results also suggested that compared with pathogen control (Figure 10E), treatment with B. subtilis L1-21 helped the successful colonization on the pathogen spores (Figure 10F).

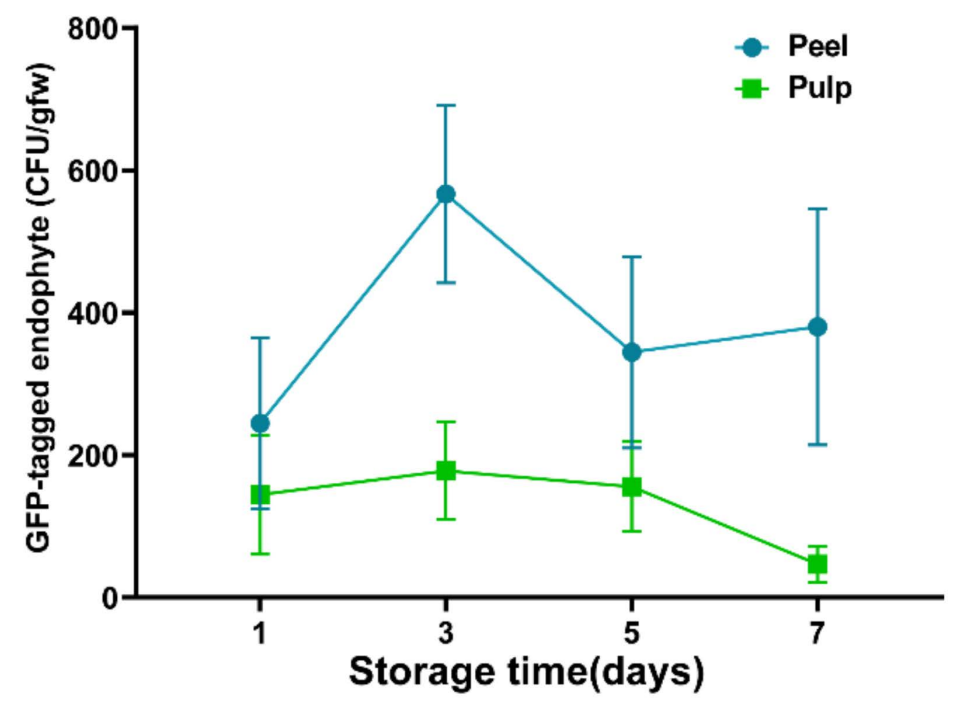

Figure 9. Colonization of Bacillus subtilis L1-21 on citrus fruits at different times. GFP-tagged endophyte L1-21 was used in this experiment to check the efficient colonization. 

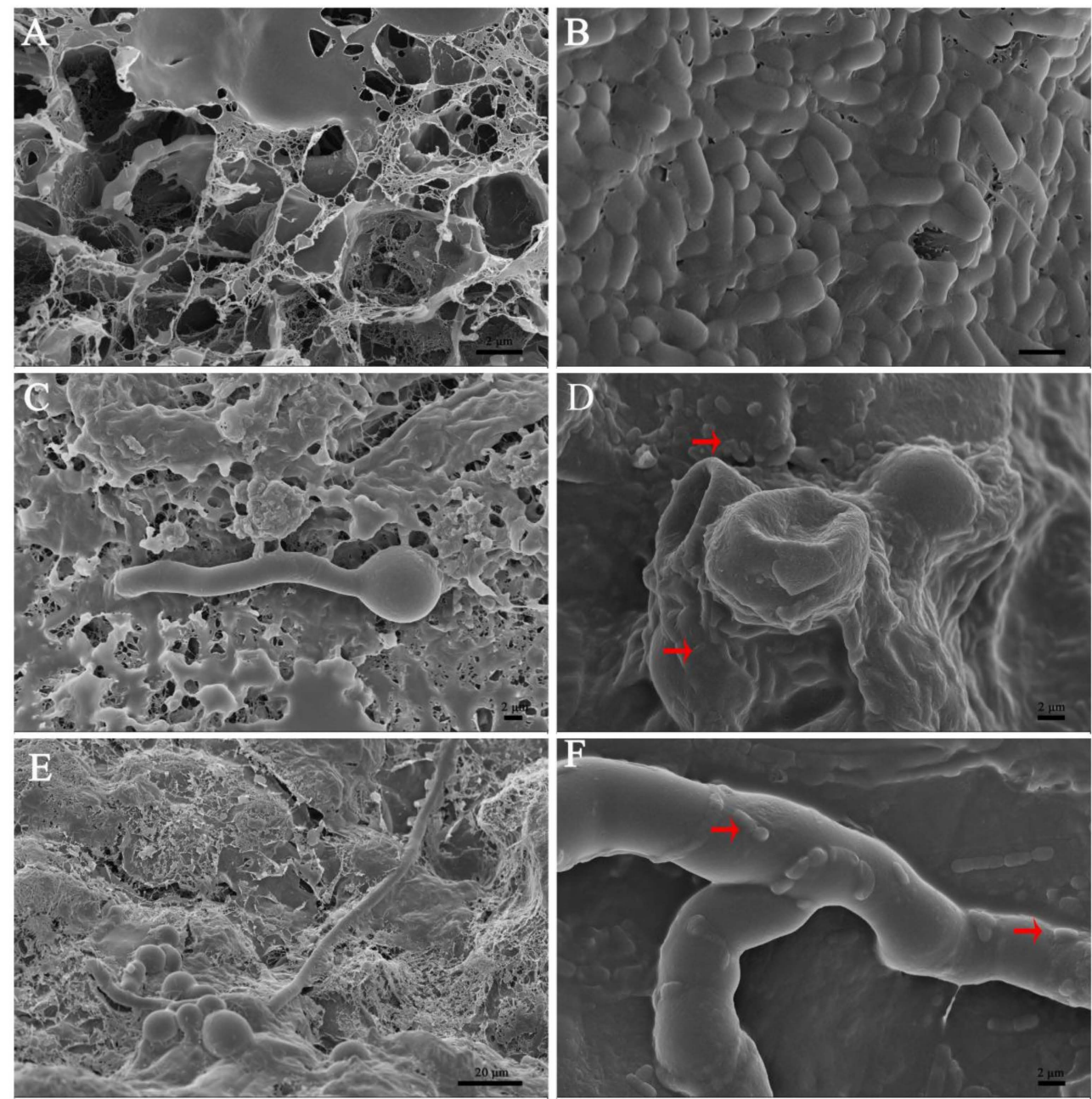

Figure 10. Scanning electron micrographs of colonization of endophyte Bacillus subtilis L1-21 on pathogens in citrus. Wound inoculation was carried out and the experiments were performed as (A) CK, 24h after treatment; (B) L1-21, $24 \mathrm{~h}$ after treatment; (C) Penicillium digitatum spore, $12 \mathrm{~h}$ after treatment, spores germinate normally; (D) P. digitatum spore + L1-21, $12 \mathrm{~h}$ after treatment, germinating spore deformity; (E) P. digitatum spores, $24 \mathrm{~h}$ after treatment; (F) P. digitatum spore + L1-21, 24 h after treatment.

\section{Discussion}

The endophyte-mediated biocontrol of fungal pathogens has been studied extensively in recent decades due to the long-lasting effects on plants [25]. The bacterial strains in the Bacillus family are generally regarded as safe for plant protection and also used as probiotic consortia to reshape the microbial diversity of the host [31]. Bacillus subtilis L1-21 is an endophytic bacterium isolated from healthy citrus plants, with a wide range of colonization host and antagonistic effects against a variety of pathogenic fungi and bacteria [13,14]. In this study, $P$. digitatum was isolated and characterized as a causing agent of citrus green mold. Our results confirmed that B. subtilis L1-21 displayed a potentially antagonistic effect on $P$. digitatum that causes citrus green mold, a postharvest disease of citrus fruit.

In this respect, different biocontrol efficacies were assessed for numerous culture filtrates of $B$. subtilis L1-21 in in vivo experiments to provide resistance against pathogen P. digitatum. Fortunately, the biocontrol efficacy of the fermentation culture was demonstrated to be better for B. subtilis L1-21. Hence, this was similar to B. subtilis L1-21 against Botrytis cinerea, as reported by Bu [13]. The supernatant of B. amyloliquefaciens DH-4 was capable against $P$. digitatum [24]. They speculated that the biocontrol efficacy of DH-4 cell suspension was not as good as that of a supernatant, which may be because DH-4 could not 
grow well and produce enough antimicrobial substances on citrus peel [24]. Experiments confirmed that B. subtilis L1-21 could colonize the peel and pulp of citrus fruit. The highest colonization was evaluated on the third day, followed by an increase to the decrease trends of endophyte cells after $7 \mathrm{~d}$. Therefore, we reasoned that the biocontrol efficacy of the cell suspension was better after $3 \mathrm{~d}$, but it decreased in $7 \mathrm{~d}$ because none of the single colony was isolated on the culture medium.

In general, Bacillus is known to produce numerous antagonistic substances against postharvest pathogens [32]. Previous studies have reported that the production of antagonistic substances depends upon the suitable culture medium. In order to increase the content of antagonistic substances, the medium were screened for the maximum production of antagonistic substances from endophytic strain B. subtilis L1-21. We examined that the inhibition rate of Landy culture filtrate was better, which suggested that Landy medium is more suitable for the extraction of antifungal compounds from B. subtilis L1-21. The selection of key medium plays an important role in the production of desired lipopeptides [33]. Previous studies also suggested that Landy medium is suitable for the production of lipopeptides from the microbial strains [34]. Apart from the medium, temperature and shaking are the other important factors that need to be considered in the long run for the production of peptides [35]. The further use of the scanning electron microscope verified that a high concentration of the B. subtilis L1-21 Landy culture filter could inhibit spore germination and the spores began to deform after $36 \mathrm{~h}$. Subsequently, a low concentration of the culture filtrate first deformed and expanded the pathogen spores, then the spores leaked, and finally, lost their vitality. In addition, a small part of the germinated spores could not normally develop into mycelium. These results provide a useful insight into the antagonistic mechanism of $B$. subtilis L1-21, which could deactivate the pathogen spores even at a lower concentration.

Further, a major hurdle in processing the potential bacterial strains for commercial purposes is the stability at a high temperature and $\mathrm{pH}$ value. We also analyzed the stability of $B$. subtilis L1-21 Landy medium's sensitivity to UV light, $4-90^{\circ} \mathrm{C}$ and different $\mathrm{pH}$ values, which showed similar results to previous reports [23]. However, the inhibition rate reduces significantly in the presence of 100 and $121{ }^{\circ} \mathrm{C}$ for $30 \mathrm{~min}$, which is not conducive to the processing of a few fungicide formulations, as fungicide formulation processing uses a high temperature and does not last for $30 \mathrm{~min}$. Hence, further investigation is required to evaluate the impact of higher temperature in a shorter time duration.

To gain further insights into the identification of antifungal compounds, we analyzed B. subtilis L1-21 Landy culture filter using LC-MS. The most featured compounds detected were surfactins, fengycins, bacillaene and bacilysin. Both surfactin and fengycin are lipopeptides that are reported to interfere with the cell membrane [36]. Li et al. [37] reported that surfactin, fengycin and bacillaene are responsible for inhibiting P. digitatum. In addition, Li et al. [37] also highlighted the antifungal activity of macroactin and iturin against $P$. digitatum, which were not detected in the Landy culture filtrate of $B$. subtilis L1-21. Bacillus sp. W176 was also found to produce macrolactin, bacillaene, mycosubtilin and surfactin against citrus green mold [23]. In this study, five surfactins and five fengycins were identified through MS/MS. However, it is not clear which monomer had the strongest antifungal activity against $P$. digitatum. Bacilysin (L-alanyl-[2,3-epoxycyclohexanone-4]-Lalanine) is a dipeptide antibiotic that shows antagonistic activity against a wide range of fungi and bacteria. Bacilysin not only inhibits fungi and bacteria, but also antagonizes cyanobacteria (Microcystis aeruginosa) [38]. However, its activity on P. digitatum has not been reported before.

In this work, we identified 13 compounds produced by B. subtilis L1-21 using GCMS. Among them, phenol attained significant antifungal activity, also reported against Fusarium oxysporum f. sp. cubense, produced by B. amyloliquefaciens NJN-6 [39]. However, dodecane produced by $B$. amyloliquefaciens NJN-6 exhibited antifungal activity against F. oxysporum f. sp. cubense. Phenylethyl alcohol showed antifungal activity against Fragaria ananassa cv. Maehyang and prolonged the postharvest life of strawberries [40]. Salmonella 
Typhi pathogen was successfully inhibited with hexadecanoic acid [41,42] whereas benzeneacetic acid demonstrated potential antagonistic activity against a variety of bacteria and fungi $[43,44]$. However, the contents of these compounds were very low, and their antifungal activity requires further verification. The substance with a retention time of 6.919 was not identified (Figure S1), and its relative content was $32.28 \%$. In summary, our results suggested that $B$. subtilis L1-21 can be cultured in Landy medium to control citrus green mold. Future work will focus on optimizing a cheaper medium that can promote a higher production of antagonistic substances and a mode of action of these components against pathogens.

\section{Conclusions}

In conclusion, we suggest that $B$. subtilis L1-21, previously used against the pathogen causing citrus huanglongbing, can play a prominent role to reduce the pathogen $P$. digitatum during fruit storage. Bacillus subtilis L1-21 produces important antifungal compounds in the form of surfactins, fengycins, bacillaene and bacilysin to mitigate the pathogen. We also highlighted that a low concentration of the B. subtilis L1-21 Landy culture filtrate was able to deform and expand the pathogen spores, which resulted in a loss of vitality. The endophyte can easily colonize in peel and pulp, providing no room for the pathogen to invade easily. The potential endophyte can serve as an important bioagent to reduce the incidence of pathogens through citrus-endophyte pathogen interaction on other kinds of citrus fruits present in the food industry. Further characterization of the molecular mechanism of $B$. subtilis L1-21 to control this pathogen will provide an exciting venue for future research.

Supplementary Materials: The following are available online at https:/ /www.mdpi.com/article/10.339 0/jof8010080/s1. Figure S1. GC-MS analysis of compounds from Bacillus subtilis L1-21, Figure S2. LCMS (A) Baciysin, $[\mathrm{M}+\mathrm{Na}]^{+}$293.17, (B) Bacillaene, $[\mathrm{M}+\mathrm{H}]^{+}$581.78. Figure S3. LC-MS fengycin A[M+H $]^{+}$ 1449.95, B $[\mathrm{M}+\mathrm{H}]^{+} 1463.97, \mathrm{C}[\mathrm{M}+\mathrm{H}]^{+} 1477.95, \mathrm{D}[\mathrm{M}+\mathrm{H}]^{+} 1491.98, \mathrm{E}[\mathrm{M}+\mathrm{H}]^{+} 1505.99$. Figure S4. LC-MS Surfactin $\mathrm{A}[\mathrm{M}+\mathrm{Na}]^{+} 1030.58, \mathrm{~B}[\mathrm{M}+\mathrm{Na}]^{+} 1044.66, \mathrm{C}[\mathrm{M}+\mathrm{Na}]^{+} 1058.66, \mathrm{D}[\mathrm{M}+\mathrm{Na}]^{+} 1072.67, \mathrm{E}[\mathrm{M}+\mathrm{Na}]^{+}$ 1086.71. Figure S5. MS/MS Surfactin A $[\mathrm{M}+\mathrm{Na}]^{+} 1030.58, \mathrm{C}_{13}$ surfactin A, B[M+Na $]^{+} 1044.66, \mathrm{C}_{14}$ surfactin $A, C[\mathrm{M}+\mathrm{Na}]^{+} 1058.66, \mathrm{C}_{15}$ surfactin $\mathrm{A}, \mathrm{D}[\mathrm{M}+\mathrm{Na}]^{+} 1072.67, \mathrm{C}_{16}$ surfactin $\mathrm{A}, \mathrm{E}[\mathrm{M}+\mathrm{Na}]^{+} 1086.71$, $\mathrm{C}_{17}$ surfactin A, F The structure of Surfactin A. Figure S6. MS/MS fengycin A[M+H] ${ }^{+} 1449.95, \mathrm{C}_{15}$ fengycin $\mathrm{A}, \mathrm{B}[\mathrm{M}+\mathrm{H}]^{+} 1463.97, \mathrm{C}_{16}$ fengycin $\mathrm{A}, \mathrm{C}[\mathrm{M}+\mathrm{H}]^{+} 1477.95, \mathrm{C}_{16}$ fengycin $\mathrm{C}, \mathrm{D}[\mathrm{M}+\mathrm{H}]^{+} 1491.98$, $\mathrm{C}_{16}$ fengycin $\mathrm{B}, \mathrm{E}[\mathrm{M}+\mathrm{H}]^{+} 1505.99, \mathrm{C}_{17}$ fengycin $\mathrm{B}, \mathrm{F}$ The structure of fengycin A, fengycin, $\mathrm{B}$ fengycin $\mathrm{C}$.

Author Contributions: Conceptualization, Y.L., P.H. (Pengbo He), P.H. (Pengfei He) and S.M.; Data curation, S.M.; Investigation, Y.L. and M.X.; Methodology, Y.L., M.X., Q.Y., X.L. and S.M.; Project administration, P.H. (Pengbo He), P.H. (Pengfei He), S.M. and Y.H.; Resources, Y.W. (Yixin Wu); Software, Y.L.; Supervision, Y.H.; Validation, Y.L., M.X. and Y.W. (Yuehu Wang); Writing-Original draft, Y.L., P.H. (Pengbo He), A.A. and S.M.; Writing-Review and editing, A.A., S.M. and Y.H. All authors have read and agreed to the published version of the manuscript.

Funding: This research was financially supported by National Natural Science Foundation of China (32050410307), Central Government Fund for Local Science and Technology Development (202107AA110007), China Postdoctoral Science Foundation (No. 2020M683664XB), Yunnan First Level Research Fund for Post-doctorate Researchers (202103). and Yunnan Oriental Training Program Funding for Post-doctorate researchers (No. YN2020409; YN2020410).

Institutional Review Board Statement: Not applicable.

Informed Consent Statement: Not applicable.

Data Availability Statement: All the data are present inside manuscript file.

Conflicts of Interest: The authors declare no conflict of interest. 


\section{References}

1. Wu, G.A.; Terol, J.; Ibanez, V.; López-García, A.; Pérez-Román, E.; Borredá, C.; Domingo, C.; Tadeo, F.R.; Carbonell-Caballero, J.; Alonso, R.; et al. Genomics of the origin and evolution of Citrus. Nature 2018, 554, 311-316. [CrossRef]

2. Spreen, T.H.; Gao, Z.; Fernandes, W.; Zansler, M.L. Chapter 23-Global economics and marketing of citrus products. In The Genus Citrus; Talon, M., Caruso, M., Gmitter, F.G., Eds.; Woodhead Publishing: Sawston, UK, 2020; pp. 471-493.

3. Wang, S.; Ruan, C.; Yi, L.; Deng, L.; Yao, S.; Zeng, K. Biocontrol ability and action mechanism of Metschnikowia citriensis against Geotrichum citri-aurantii causing sour rot of postharvest citrus fruit. Food Microbiol. 2020, 87, 103375. [CrossRef]

4. Lucon, C.M.M.; Guzzo, S.D.; de Jesus, C.O.; Pascholati, S.F.; de Goes, A. Postharvest harpin or Bacillus thuringiensis treatments suppress citrus black spot in 'Valencia' oranges. Crop Prot. 2010, 29, 766-772. [CrossRef]

5. Costa, J.H.; Bazioli, J.M.; de Moraes Pontes, J.G.; Fill, T.P. Penicillium digitatum infection mechanisms in citrus: What do we know so far? Fungal Biol. 2019, 123, 584-593. [CrossRef] [PubMed]

6. Marcet-Houben, M.; Ballester, A.R.; de la Fuente, B.; Harries, E.; Marcos, J.F.; González-Candelas, L.; Gabaldón, T. Genome sequence of the necrotrophic fungus Penicillium digitatum, the main postharvest pathogen of citrus. BMC Genom. 2012, 13, 646. [CrossRef] [PubMed]

7. Elsherbiny, E.A.; Dawood, D.H.; Safwat, N.A. Antifungal action and induction of resistance by $\beta$-aminobutyric acid against Penicillium digitatum to control green mold in orange fruit. Pestic. Biochem. Physiol. 2021, 171, 104721. [CrossRef] [PubMed]

8. Njombolwana, N.S.; Erasmus, A.; Fourie, P.H. Evaluation of curative and protective control of Penicillium digitatum following imazalil application in wax coating. Postharvest Biol. Technol. 2013, 77, 102-110. [CrossRef]

9. Chen, C.; Wan, C.; Peng, X.; Chen, J. A flavonone pinocembroside inhibits Penicillium italicum growth and blue mold development in 'Newhall' navel oranges by targeting membrane damage mechanism. Pestic. Biochem. Physiol. 2020, 165, 104505. [CrossRef]

10. Talibi, I.; Boubaker, H.; Boudyach, E.H.; Ait Ben Aoumar, A. Alternative methods for the control of postharvest citrus diseases. J. Appl. Microbiol. 2014, 117, 1-17. [CrossRef]

11. Cui, W.; He, P.; Munir, S.; He, P.; Li, X.; Li, Y.; Wu, J.; Wu, Y.; Yang, L.; He, Y. Efficacy of plant growth promoting bacteria Bacillus amyloliquefaciens B9601-Y2 for biocontrol of southern corn leaf blight. Biol. Control 2019, 139, 104080. [CrossRef]

12. Munir, S.; Ahmed, A.; Li, Y.; He, P.; Singh, B.K.; He, P.; Li, X.; Asad, S.; Wu, Y.; He, Y. The hidden treasures of citrus: Finding Huanglongbing cure where it was lost. Crit. Rev. Biotechnol. 2021, 2021, 1-16. [CrossRef] [PubMed]

13. Bu, S.; Munir, S.; He, P.; Li, Y.; Wu, Y.; Li, X.; Kong, B.; He, P.; He, Y. Bacillus subtilis L1-21 as a biocontrol agent for postharvest gray mold of tomato caused by Botrytis cinerea. Biol. Control 2021, 157, 104568. [CrossRef]

14. Munir, S.; Li, Y.; He, P.; He, P.; Ahmed, A.; Wu, Y.; He, Y. Unraveling the metabolite signature of citrus showing defense response towards Candidatus Liberibacter asiaticus after application of endophyte Bacillus subtilis L1-21. Microbiol. Res. 2020, 234,126425 [CrossRef] [PubMed]

15. Jiao, R.; Munir, S.; He, P.; Yang, H.; Wu, Y.; Wang, J.; He, P.; Cai, Y.; Wang, G.; He, Y. Biocontrol potential of the endophytic Bacillus amyloliquefaciens YN201732 against tobacco powdery mildew and its growth promotion. Biol. Control 2020, 143, 104160. [CrossRef]

16. Arrebola, E.; Sivakumar, D.; Korsten, L. Effect of volatile compounds produced by Bacillus strains on postharvest decay in citrus. Biol. Control 2010, 53, 122-128. [CrossRef]

17. Cheffi, M.; Chenari Bouket, A.; Alenezi, F.N.; Luptakova, L.; Belka, M.; Vallat, A.; Rateb, M.E.; Tounsi, S.; Triki, M.A.; Belbahri, L. Olea europaea L. root endophyte Bacillus velezensis OEE1 counteracts oomycete and fungal harmful pathogens and harbours a large repertoire of secreted and volatile metabolites and beneficial functional genes. Microorganisms 2019, 7, 314. [CrossRef] [PubMed]

18. Waewthongrak, W.; Pisuchpen, S.; Leelasuphakul, W. Effect of Bacillus subtilis and chitosan applications on green mold (Penicilium digitatum Sacc.) decay in citrus fruit. Postharvest Biol. Technol. 2015, 99, 44-49. [CrossRef]

19. Leelasuphakul, W.; Hemmanee, P.; Chuenchitt, S. Growth inhibitory properties of Bacillus subtilis strains and their metabolites against the green mold pathogen (Penicillium digitatum Sacc.) of citrus fruit. Postharvest Biol. Technol. 2008, 48, 113-121. [CrossRef]

20. Wang, Z.; Jiang, M.; Chen, K.; Wang, K.; Du, M.; Zalán, Z.; Hegyi, F.; Kan, J. Biocontrol of Penicillium digitatum on postharvest citrus fruits by Pseudomonas fluorescens. J. Food Qual. 2018, 2018, 2910481. [CrossRef]

21. Lai, K.; Chen, S.; Hu, M.; Hu, Q.; Geng, P.; Weng, Q.; Jia, J. Control of postharvest green mold of citrus fruit by application of endophytic Paenibacillus polymyxa strain SG-6. Postharvest Biol. Technol. 2012, 69, 40-48. [CrossRef]

22. Liu, X.; Wang, J.; Gou, P.; Mao, C.; Zhu, Z.-R.; Li, H. In vitro inhibition of postharvest pathogens of fruit and control of gray mold of strawberry and green mold of citrus by aureobasidin A. Int. J. Food Microbiol. 2007, 119, 223-229. [CrossRef] [PubMed]

23. Tian, Z.; Chen, C.; Chen, K.; Liu, P.; Fan, Q.; Zhao, J.; Long, C.A. Biocontrol and the mechanisms of Bacillus sp. w176 against postharvest green mold in citrus. Postharvest Biol. Technol. 2020, 159, 111022. [CrossRef]

24. Chen, K.; Tian, Z.; Luo, Y.; Cheng, Y.; Long, C.A. Antagonistic activity and the mechanism of Bacillus amyloliquefaciens DH-4 against citrus green mold. Phytopathology 2018, 108, 1253-1262. [CrossRef]

25. Ahmed, A.; Munir, S.; He, P.; Li, Y.; He, P.; Yixin, W.; He, Y. Biocontrol arsenals of bacterial endophyte: An imminent triumph against clubroot disease. Microbiol. Res. 2020, 241, 126565. [CrossRef]

26. Jiao, R.; Cai, Y.; He, P.; Munir, S.; Li, X.; Wu, Y.; Wang, J.; Xia, M.; He, P.; Wang, G.; et al. Bacillus amyloliquefaciens YN201732 produces lipopeptides with promising biocontrol activity against fungal pathogen Erysiphe cichoracearum. Front. Cell. Infect. Microbiol. 2021, 11, 999. [CrossRef] [PubMed]

27. Chai, Y.; Winans, S.C. RepB protein of an Agrobacterium tumefaciens Ti plasmid binds to two adjacent sites between repA and repB for plasmid partitioning and autorepression. Mol. Microbiol. 2005, 58, 1114-1129. [CrossRef] [PubMed] 
28. Munir, S.; Li, Y.; He, P.; Huang, M.; He, P.; He, P.; Cui, W.; Wu, Y.; He, Y. Core endophyte communities of different citrus varieties from citrus growing regions in China. Sci. Rep. 2020, 10, 3648. [CrossRef]

29. Yu, L.; Li, X.; Lan, H.J. Effect of bacteriostaticon Penicillium italicum in stored citruses by using the extracts of Ginkgo bilobaleaves. Food. Mach. 2010, 6, 60-62.

30. Li, X.; Munir, S.; Xu, Y.; Wang, Y.; He, Y. Combined mass spectrometry-guided genome mining and virtual screening for acaricidal activity in secondary metabolites of Bacillus velezensis W1. R. Soc. Chem. 2021, 11, 25441-25449. [CrossRef]

31. Zhang, J.; Wei, L.; Yang, J.; Ahmed, W.; Wang, Y.; Fu, L.; Ji, G. Probiotic consortia: Reshaping the rhizospheric microbiome and its role in suppressing root-rot disease of Panax notoginseng. Front. Microbiol. 2020, 11, 701. [CrossRef]

32. Papoutsis, K.; Mathioudakis, M.M.; Hasperué, J.H.; Ziogas, V.J. Non-chemical treatments for preventing the postharvest fungal rotting of citrus caused by Penicillium digitatum (green mold) and Penicillium italicum (blue mold). Trends Food Sci. Technol. 2019, 86, 479-491. [CrossRef]

33. De Andrade, C.J.; de Andrade, L.M.; Bution, M.L.; Dolder, M.A.H.; Barros, F.F.C.; Pastore, G.M. Optimizing alternative substrate for simultaneous production of surfactin and 2, 3-butanediol by Bacillus subtilis LB5a. Biocatal. Agric. Biotechnol. 2016, 6, 209-218. [CrossRef]

34. Sun, D.; Liao, J.; Sun, L.; Wang, Y.; Liu, Y.; Deng, Q.; Zhang, N.; Xu, D.; Fang, Z.; Wang, W.J. Effect of media and fermentation conditions on surfactin and iturin homologues produced by Bacillus natto NT-6: LC-MS analysis. AMB Express 2019, 9, 120. [CrossRef]

35. Fahim, S.; Dimitrov, K.; Gancel, F.; Vauchel, P.; Jacques, P.; Nikov, I. Impact of energy supply and oxygen transfer on selective lipopeptide production by Bacillus subtilis BBG21. Bioresour. Technol. 2012, 126, 1-6. [CrossRef]

36. Pupin, M.; Flissi, A.; Jacques, P.; Leclère, V.J. Bioinformatics tools for the discovery of new lipopeptides with biocontrol applications. Eur. J. Plant Pathol. 2018, 152, 993-1001. [CrossRef]

37. Li, L.; Xin, Z.; Okwong, R.O.; OuYang, Q.; Che, J.; Zhou, J.; Tao, N. Antofine inhibits postharvest green mold due to imazalilresistant Penicillium digitatum strain Pdw03 by triggering oxidative burst. J. Fish Biol. 2021, 45, e13751. [CrossRef] [PubMed]

38. Wu, L.; Wu, H.; Chen, L.; Xie, S.; Zang, H.; Borriss, R.; Gao, X. Bacilysin from Bacillus amyloliquefaciens FZB42 has specific bactericidal activity against harmful algal bloom species. Appl. Environ. Microbiol. 2014, 80, 7512-7520. [CrossRef] [PubMed]

39. Yuan, J.; Raza, W.; Shen, Q.; Huang, Q. Antifungal activity of Bacillus amyloliquefaciens NJN-6 volatile compounds against Fusarium oxysporum f. sp. cubense. Appl. Environ. Microbiol. 2012, 78, 5942-5944. [CrossRef]

40. Mo, E.K.; Sung, C.K. Phenylethyl alcohol (PEA) application slows fungal growth and maintains aroma in strawberry. Postharvest Biol. Technol. 2007, 45, 234-239. [CrossRef]

41. Johannes, E.; Litaay, M. The bioactivity of hexadecanoic acid compound isolated from hydroid Aglaophenia cupressina Lamoureoux as antibacterial agent against Salmonella typhi. Int. J. Biol. Med. Res. 2016, 7, 5469-5472.

42. Al-Marzoqi, A.H.; Hameed, I.H.; Idan, S.A. Analysis of bioactive chemical components of two medicinal plants (Coriandrum sativum and Melia azedarach) leaves using gas chromatography-mass spectrometry (GC-MS). Afr. J. Biotechnol. 2015, 14, $2812-2830$.

43. Jeyadevi, R.; Sivasudha, T.; Ilavarasi, A.; Thajuddin, N. Chemical constituents and antimicrobial activity of Indian green leafy vegetable Cardiospermum halicacabum. Indian J. Microbiol. 2013, 53, 208-213. [CrossRef] [PubMed]

44. Al-Dhabi, N.A.; Esmail, G.A.; Duraipandiyan, V.; Arasu, M.V.; Salem-Bekhit, M.M. Isolation, identification and screening of antimicrobial thermophilic Streptomyces sp. Al-Dhabi-1 isolated from Tharban hot spring, Saudi Arabia. Extremophiles 2016, 20, 79-90. [CrossRef] [PubMed] 